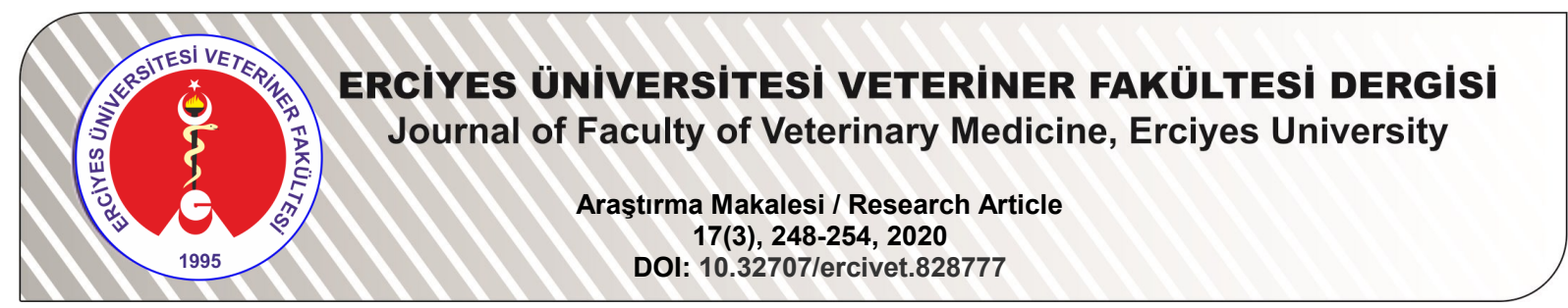

The Comparison of Saturated and Unsaturated Fatty Acid Compositions in Safflower Herbage and Safflower Straw as Alternative Forage for Ruminant

\begin{abstract}
Kanber KARA ${ }^{1}$
${ }^{1}$ Erciyes University, Faculty of Veterinary Medicine, Department of Animal Nutrition and Nutritional Diseases, Kayseri-TURKEY

Corresponding author: Kanber KARA; E-mail: karakanber@hotmail.com; kanberkara@erciyes.edu.tr; ORCID: 0000-00019867-1344

How to cite: Kara K. The comparison of saturated and unsaturated fatty acid compositions in safflower herbage and safflower straw as alternative forage for ruminant. Erciyes Univ Vet Fak Derg 2020; 17(3): 248-254.

Summary: In this study, it was aimed to investigate the saturated and unsaturated fatty acid compositions in herbage and straw of safflower (Carthamus tinctorius L. Dinçer; thornless) plant as alternative forage for ruminant. Major fatty acids in safflower herbage and safflower straw were determined as linoleic, palmitic, oleic and stearic acids. The proportions of myristic, pentadecanoic, cis-10-pentadecenoic, palmitic, palmitoleic, cis-10-pentadecenoic, $\alpha$-linolenic, ciseicosatrienoic, erucic, cis-docosahexaenoic, tricosanoic and lignoceric acids in total fat acids of safflower herbage were higher than those of safflower straw $(\mathrm{P}<0.01)$. The proportions of margaric, stearic, elaidic, oleic, linoleic, cis-11eicoenioic, arachidonic, cis-eicosapentaenoic and nervonic acids in total fatty acids of safflower herbage were lower than those of safflower straw $(P<0.001)$. The proportions of saturated fatty acid (SFA), medium-chain fatty acids (MCFA), very-long-chain fatty acids (VLCFA) and $w-3$, and $w-3 / w-6$ ratio for fatty acids of safflower herbage were higher than those of safflower straw $(P<0.001)$. The proportions of unsaturated fatty acid (UFA), monounsaturated fatty acid (MUFA), polyunsaturated fatty acid (PUFA), w- $6, w-9$ and long-chain fatty acids (LCFA) in total fatty acids of safflower straw were higher than those of safflower herbage $(P<0.001)$. Palmitic, stearic, oleic and linoleic acids contents as $\mathrm{mg} /$ $\mathrm{g}$ in dry matter (DM) of safflower herbage were lower than those of safflower straw. As a result, safflower herbage and safflower straw had a rich fatty acid content in $\mathrm{mg} / \mathrm{g} \mathrm{DM}$. The proportions and amounts of essential fatty acids in safflower straw, which have important biological activity, were higher than safflower herbage. In general, these feedstuffs stand out as rich alternative forages in w- 3 and w- 6 fatty acids.
\end{abstract}

Key words: Safflower, forage, fatty acids, omega 3, omega 6

\title{
Ruminantlar için Alternatif Kaba Yem Olarak Aspir Yeşil Otu ve Aspir Samanının Doymuş ve Doymamış Yağ
} Asiti Kompozisyonunun Karşılaştırılması

Özet: Bu çalışmada, ruminantlar için alternatif kaba yem olarak aspir (Carthamus tinctorius L. Dinçer; dikensiz) bitkisinin yeşil ot ve samanındaki doymuş ve doymamış yağ asidi bileşenlerinin araştırımasını amaçlanmıştır. Aspir yeşil otu ve samanındaki en yüksek oranda bulunan yağ asitleri linoleik, palmitik, oleik ve stearik asit olarak belirlendi. Aspir yeşil otunun toplam yağ asitleri içindeki miristik, pentadekanoik, cis-10-pentadekanoik, palmitik, palmitoleik, cis-10pentadekanoik, a-linolenik, cis-eikosatrienoik, erüsik, cis-dokosaheksaenoik, tricosanoik ve lignoserik asitlerin oranları aspir samanındakinden yüksekti $(P<0.01)$. Aspir yeşil otunun toplam yağ asitleri içinde margarik, stearik, elaidik, oleik, linoleik, cis-11-eikoenyonik, araşidonik, cis-eikosapentaenoik ve nervonik asitlerin oranları aspir samanınınkinden daha düşüktü $(P<0.001)$. Aspir yeşil otunun toplam asitlerinde doymuş yağ asidi $(S F A)$, orta zincirli yağ asitleri (MCFA), çok uzun zincirli yağ asitleri (VLCFA) ve w-3 oranları ile w-3/w-6 oranı aspir samanından daha yüksekti $(P<0.001)$. Aspir samanının toplam yağ asitlerindeki doymamış yağ asidi (UFA), tekli doymamış yağ asidi (MUFA), çoklu doymamış yağ asidi (PUFA), w-6, w-9 ve uzun zincirli yağ asitleri (LCFA) oranları aspir yeşil otununkinden daha yüksekti $(P<0.001)$. Aspir otunun kuru maddesinde (KM) mg/g olarak palmitik, stearik, oleik ve linoleik asit içerikleri, aspir samanından daha düşüktü. Sonuç olarak, aspir yeşil otu ve aspir samanı $(\mathrm{mg} / \mathrm{g} \mathrm{KM})$ zengin bir yağ asidi içeriğine sahipti. Aspir samanının önemli biyolojik aktiviteye sahip olan esansiyel yağ asitlerin oranı ve miktarı aspir yeşil otundan daha yüksekti. Genel olarak, bu yemler w-3 ve w-6 yağ asitleri bakımından zengin alternatif kaba yemler olarak öne çıkmaktadır. Anahtar kelimeler: Aspir, kaba yem, omega 3, omega 6, yağ asiti

\section{Introduction}

Safflower, which belongs to Carthamus tinctorious $\mathrm{L}$ species in the Asteraceae family, can be planted in winter or summer, or as a crop rotation plant. This plant is one of the earliest crops used by humans and

Geliş Tarihi/Submission Date : 30.06 .2020 Kabul Tarihi/Accepted Date $\quad: 24.08 .2020$ can be grown in different climatic conditions and soil types. It is an annual and is stake rooted; and there are thorny and thorn-less species and it is an oil-seed plant which can include $70-80 \%$ linoleic acid or $80 \%$ oleic acid in oils (Landau et al., 2004; Baumler et al., 2006; Gilbert, 2008). Safflower, which has attracted attention as a food crop resistant to drought, is of extreme importance today due to the effects of global 
warming (Altin et al., 2012). Previous researcher identified that the safflower herbage included 8.0$13.8 \%$ crude protein (CP), 39-42\% neutral detergent fibre (NDF), 4.75-6.67\% lignin, 0.4-0.7\% tannin, 0.2$0.4 \%$ non-protein nitrogen in total nitrogen and 2040 kcal metabolic energy (ME) /kg DM for ruminant (Asgharzadeh et al., 2013; Cagri and Kara 2018) and safflower straw included about 4\% CP 50\% NDF, $6.6 \%$ lignin and $1628 \mathrm{kcal} \mathrm{ME} / \mathrm{kg} \mathrm{DM}$ for ruminant (Cagri and Kara 2018). The previously mentioned nutrient content of safflower herbage shows that it is a mid-quality roughage. Despite its thorny leaves, it can be consumed by sheep and goats. In previous study, it has been shown that the preference of safflower straw by sheep and dairy cattle was very close to that of wheat straw (Landau et al., 2005). The safflower herbage and safflower straw has been used as forage in the diets of cows in Australia and sheep in Italy (Landau et al., 2004 and 2005). Cagri and Kara (2018) stated that safflower herbage and safflower straw at $5 \%-20 \%$ ratio in a horse's diet had a positive effect on the in vitro gas production, metabolic energy, short chain fatty acid, and gas yield at $24 \mathrm{~h}$. The use of up to $20 \%$ safflower herbage and safflower straw in ration had no negative effect on the digestion parameters of ruminant and horse (Cagri and Kara, 2018). These researchers concluded that using safflower herbage and safflower straw in ration up to $20 \%$ has the potential to be good forage sources in the diets of horses and ruminants.

The planting area of safflower in Turkey has reached to 200000 decares/year from 1000 decares/year for the last 10 years (TUIK, 2020). As a result of the increase in safflower cultivation, the use of safflower by -products, hay and other roughage elements, in the feeding of animals has gained importance. While constructing this study, we were curious whether the fatty acid profile in the ingredients of this alternative oilseed by-product is roughage. The aim of this study was to determine the proportions (as \% in total fatty acids) and amounts (as mg/g DM) of 37 different fatty acid of safflower herbage and safflower straw samples.

\section{Material and Methods}

\section{The samples of safflower herbage and safflower straw}

The safflower (Carthamus tinctorius L. Dinçer) samples used in the present study were collected from the province of Kırşehir, Turkey. The Dinçer type safflower is without thorns. Kırşehir Province has arid conditions and desert-like steppe vegetation due to temperature and rainfall (Altin et al., 2012). The safflower herbage samples were chopped $1 \mathrm{~cm}$ above the soil, included the aerial parts (leaf, stem, preflowering bud) at pre-flowering stage. The safflower straw samples were taken from the mature plant resi- due after the plant was harvested for the grain. Approximately $500 \mathrm{~g}$ of samples of safflower herbage and safflower straw were used for fatty acid analyses.

\section{The determination of fatty acid compositions}

The samples of safflower herbage and safflower straw were dried at thermostatically controlled cabinet. The fat extractions of samples were carried out according to soxhlet process (AOAC, 1995). For fatty acid analyses, the fat samples of feedstuffs were methylated with the three-stage modified (Kara, 2020) procedure of Wang et al. (2015). According to this procedure, $40 \mu \mathrm{L}$ of fat in falcon tubes with $15 \mathrm{~mL}$ volumes were mixed with $0.7 \mathrm{ml}$ of $\mathrm{KOH}(10 \mathrm{M})$ and $5.3 \mathrm{~mL}$ of methanol and was vortexed. The mixture was incubated for $45 \mathrm{~min}$ at $55^{\circ} \mathrm{C}$ in an incubator (Nüve, Turkey) and cooled to $21^{\circ} \mathrm{C}$. The mixture was combined with $0.58 \mathrm{~mL}$ of $\mathrm{H}_{2} \mathrm{SO}_{4}(10 \mathrm{M})$ and was vortexed. After this mixture was incubated for $45 \mathrm{~min}$ at $55^{\circ} \mathrm{C}$, was added $3 \mathrm{~mL}$ of $\mathrm{n}$-hexane. The tubes were centrifuged for $5 \mathrm{~min}$ at $4000 \mathrm{rpm}$. The supernatants (fatty acids in n-hexane) were taken in a $1.5 \mathrm{ml}$ screw neck ND-9 amber vial with $9 \mathrm{~mm}$ screw caps (silicone white/PTFE caps) and analyzed in a gas chromatograph (TRACE 1300, Thermo Scientific, USA) with automatic sampling (Thermo Al 1310, Thermo Scientific, USA). FAME mix (37C) standard solution (CL.40.13093.0001) in dichloromethane (Chem-Lab, Zedelgem, Belgium) was used for the identification of peak. The device was studied FAME column (Leigh $60 \mathrm{~m}$, I.D: $0.25 \mathrm{~mm}$, film: $0.25 \mu \mathrm{m}$ and maximum temperature $250-260^{\circ} \mathrm{C}$ ) and injection split temperature $255^{\circ} \mathrm{C}$, colon $140{ }^{\circ} \mathrm{C}$ and flow rate $30 \mathrm{ml} /$ min processing method for 42 minutes. Fatty acid identification was performed by comparing the peaks in the chromatogram with the retention times at the standard (Kramer et al., 1997). Saturated fatty acid (SFA), unsaturated fatty acid (UFA), polyunsaturated fatty acid (PUFA), monounsaturated fatty acid (MUFA), medium-chain fatty acids (MCFA), longchain fatty acids (LCFA) and very-long-chain fatty acids (VLCFA) were detected.

\section{Statistical analysis}

SPSS 17.0 software was used for statistical analysis of the data obtained from the studies. The data were analyzed with the $t$-test. Statistical significance was taken below $0.05(P<0.05)$.

\section{Results}

The fat content in safflower herbage and safflower straw in the present study were 1.45 and $2.46 \%$ in $\mathrm{DM}$, respectively. The proportions of C8:0-C18:0 fatty acids in total fatty acids of safflower herbage and safflower straw had a difference. The proportions of capriylic, capric, undecanoic, lauric, tridecanoic, myristoleic and linolelaidic acids in total fatty acids of safflower herbage and safflower straw were same 
Table 1. The compositions of individual C8:0 - C18:0 fatty acids (as \% in total fatty acids) in safflower herbage and safflower straw

\begin{tabular}{lcccccc}
\hline Fatty Acids & Safflower & $\begin{array}{c}\text { Safflower } \\
\text { straw }\end{array}$ & SEM & SD & P value \\
\hline Caprylic Acid & $\mathbf{C 8 : 0}$ & 0.10 & 0.11 & 0.002 & 0.005 & $\mathrm{P}>0.05$ \\
Capric Acid & $\mathbf{C 1 0 : 0}$ & 0.15 & 0.13 & 0.004 & 0.010 & $\mathrm{P}>0.05$ \\
Undecanoic Acid & $\mathbf{C 1 1 : 0}$ & 0.06 & 0.06 & 0.001 & 0.001 & $\mathrm{P}>0.05$ \\
Lauric Acid & $\mathbf{C 1 2 : 0}$ & 0.30 & 0.22 & 0.017 & 0.043 & $\mathrm{P}>0.05$ \\
Tridecanoic Acid & $\mathbf{C 1 3 : 0}$ & 0.03 & 0.02 & 0.002 & 0.005 & $\mathrm{P}>0.05$ \\
Myristic Acid & $\mathbf{C 1 4 : 0}$ & 1.68 & 0.96 & 0.161 & 0.394 & $\mathrm{P}<0.001$ \\
Myristoleic Acid & $\mathbf{C 1 4 : 1}$ & 0.05 & 0.04 & 0.002 & 0.005 & $\mathrm{P}>0.05$ \\
Pentadecanoic Acid & $\mathbf{C 1 5 : 0}$ & 0.46 & 0.12 & 0.076 & 0.186 & $\mathrm{P}<0.001$ \\
cis-10-Pentadecenoic Acid & $\mathbf{C 1 5 : 1}$ & 0.02 & 0.00 & 0.006 & 0.015 & $\mathrm{P}<0.001$ \\
Palmitic Acid & $\mathbf{C 1 6 : 0}$ & 25.95 & 17.25 & 1.946 & 4.768 & $\mathrm{P}<0.001$ \\
Palmitoleic Acid & $\mathbf{C 1 6 : 1}$ & 1.25 & 1.09 & 0.037 & 0.091 & $\mathrm{P}<0.001$ \\
Margaric Acid & $\mathbf{C 1 7 : 0}$ & 0.03 & 0.19 & 0.037 & 0.091 & $\mathrm{P}<0.001$ \\
cis-10-Heptadecenoic Acid & $\mathbf{C 1 7 : 1}$ & 0.39 & 0.20 & 0.044 & 0.107 & $\mathrm{P}<0.001$ \\
Stearic Acid & $\mathbf{C 1 8 : 0}$ & 5.60 & 6.93 & 0.297 & 0.728 & $\mathrm{P}<0.001$ \\
Elaidic Acid & $\mathbf{C 1 8 : 1 n 9 t}$ & 0.05 & 0.08 & 0.008 & 0.020 & $\mathrm{P}<0.001$ \\
Oleic Acid & $\mathbf{C 1 8 : 1 n 9 c}$ & 13.34 & 20.31 & 1.560 & 3.820 & $\mathrm{P}<0.001$ \\
Linolelaidic Acid & $\mathbf{C 1 8 : 2 n 6 t}$ & 0.28 & 0.00 & 0.062 & 0.153 & $\mathrm{P}>0.05$ \\
Linoleic Acid & $\mathbf{C 1 8 : 2 n 6 c}$ & 28.11 & 48.72 & 4.610 & 11.292 & $\mathrm{P}<0.001$ \\
a-Linolenic Acid & $\mathbf{C 1 8 : 3 n 3}$ & 16.59 & 0.17 & 3.673 & 8.997 & $\mathrm{P}<0.001$ \\
\hline SD: Standard Deviation
\end{tabular}

SD: Standard Deviation of Means, SEM: Standard Error of Means

$(\mathrm{P}>0.05)$. The proportion $(1.68 \%)$ of myristic acid in total fatty acids of safflower herbage was higher than that $(0.96 \%)$ of safflower straw $(P<0.001)$. The proportions of pentadecanoic acid, cis-10-pentadecenoic acid, palmitic acid, palmitoleic acid, cis-10pentadecenoic acid, $\alpha$-linolenic acids in total fatty acids of safflower herbage were higher than those of safflower straw $(\mathrm{P}<0.001)$. The proportions of margaric acid, stearic acid, elaidic acid, oleic acid and linoleic acid in total fatty acids of safflower herbage were lower than those of safflower straw $(P<0.001)$ (Table 1).

The proportions of C20:0 - C24:0 fatty acids (as \% in total fatty acids) in forages in present study has change. The compositions of arachidic acid, cis11,14,17-eicosadienoic acid, heneicosanoic acid and cis-13,16-docosadienoic acid in total fatty acids of safflower herbage and safflower straw was not different $(P>0.05)$. The compositions of cis-11-eicoenioic acid, arachidonic acid, cis-5,8,11,14,17eicosapentaenoic acid and nervonic acid of safflower straw were higher than those of safflower herbage $(P<0.001)$. The proportions of cis-11,14,17eicosatrienoic acid, erucic acid, cis-4,7,10,13,16,19docosahexaenoic acid, tricosanoic acid and lignoceric acid in total fatty acids of safflower herbage were higher than those of safflower straw $(P<0.01)$

Table 2. The compositions of individual C20:0 - C24:0 fatty acids (as \% in total fatty acids) in safflower herbage and safflower straw

\begin{tabular}{|c|c|c|c|c|c|c|}
\hline Fatty Acids & & $\begin{array}{c}\text { Safflower } \\
\text { herbage }\end{array}$ & $\begin{array}{c}\text { Safflower } \\
\text { straw }\end{array}$ & SEM & SD & $P$ value \\
\hline Arachidic Acid & C20:0 & 0.02 & 0.00 & 0.004 & 0.010 & $P>0.05$ \\
\hline cis-11-Eicoenioic Acid & $\mathrm{C} 20: 1$ & 0.17 & 0.27 & 0.022 & 0.055 & $P<0.001$ \\
\hline cis-11,14,17-Eicosadienoic Acid & $\mathrm{C} 20: 2$ & 0.02 & 0.07 & 0.021 & 0.053 & $\mathrm{P}>0.05$ \\
\hline cis-11,14,17-Eicosatrienoic Acid & C20:3n3 & 0.94 & 0.13 & 0.179 & 0.440 & $P<0.001$ \\
\hline Arachidonic Acid & $\mathrm{C} 20: 4 \mathrm{n} 6$ & 0.23 & 0.26 & 0.008 & 0.020 & $P<0.001$ \\
\hline cis-5,8,11,14,17-Eicosapentaenoic Acid & C20:5n3 & 0.04 & 0.80 & 0.168 & 0.412 & $P<0.001$ \\
\hline Heneicosanoic Acid & C21:0 & 0.17 & 0.23 & 0.028 & 0.068 & $\mathrm{P}>0.05$ \\
\hline cis-13,16-Docosadienoic Acid & $\mathrm{C} 22: 2$ & 1.23 & 0.80 & 0.096 & 0.235 & $\mathrm{P}>0.05$ \\
\hline Erucic Acid & $\mathrm{C} 22: 1 \mathrm{n} 9$ & 0.22 & 0.10 & 0.029 & 0.071 & $\mathrm{P}<0.001$ \\
\hline cis-4,7,10,13,16,19-Docosahexaenoic Acid & $\mathrm{C} 22: 6 \mathrm{n} 3$ & 0.09 & 0.03 & 0.016 & 0.039 & $P<0.01$ \\
\hline Tricosanoic Acid & C23:0 & 0.83 & 0.08 & 0.167 & 0.410 & $P<0.001$ \\
\hline Lignoceric Acid & $\mathrm{C} 24: 0$ & 1.43 & 0.29 & 0.265 & 0.650 & $P<0.01$ \\
\hline Nervonic Acid & $\mathrm{C} 24: 1$ & 0.06 & 0.30 & 0.055 & 0.135 & $P<0.001$ \\
\hline
\end{tabular}

SD: Standard Deviation of Means, SEM: Standard Error of Means 
Table 3. Compositions of fatty acids (as \% in total fatty acids) of safflower herbage and safflower straw

\begin{tabular}{lccccc}
\hline & $\begin{array}{c}\text { Safflower } \\
\text { herbage }\end{array}$ & $\begin{array}{c}\text { Safflower } \\
\text { straw }\end{array}$ & SD & SEM & P value \\
\hline SFA & 36.94 & 26.61 & 5.65 & 2.31 & $\mathrm{P}<0.001$ \\
UFA & 63.12 & 73.39 & 5.62 & 2.29 & $\mathrm{P}<0.001$ \\
MUFA & 15.57 & 22.40 & 3.74 & 1.52 & $\mathrm{P}<0.001$ \\
PUFA & 47.55 & 50.99 & 0.78 & 0.05 & $\mathrm{P}<0.001$ \\
w-3 & 17.67 & 1.13 & 9.06 & 3.69 & $\mathrm{P}<0.001$ \\
w-6 & 29.87 & 49.86 & 10.94 & 4.46 & $\mathrm{P}<0.001$ \\
w-9 & 13.83 & 20.80 & 3.81 & 1.55 & $\mathrm{P}<0.001$ \\
w-3/w-6 & 0.59 & 0.02 & 0.31 & 0.12 & $\mathrm{P}<0.001$ \\
MCFA & 0.66 & 0.52 & 0.07 & 0.03 & $\mathrm{P}<0.001$ \\
LCFA & 95.26 & 97.62 & 1.30 & 0.53 & $\mathrm{P}<0.001$ \\
VLCFA & 4.06 & 1.84 & 1.23 & 0.50 & $\mathrm{P}<0.001$ \\
\hline
\end{tabular}

SD: Standard Deviation of Means, SEM: Standard Error of Means

LCFA: Long chain fatty acids, MCFA: Medium chain fatty acids, MUFA: Monounsaturated fatty acids, PUFA: Polyunsaturated fatty acids, SFA: Saturated fatty acids, UFA: Unsaturated fatty acids, VLCFA: Very long chain fatty acids

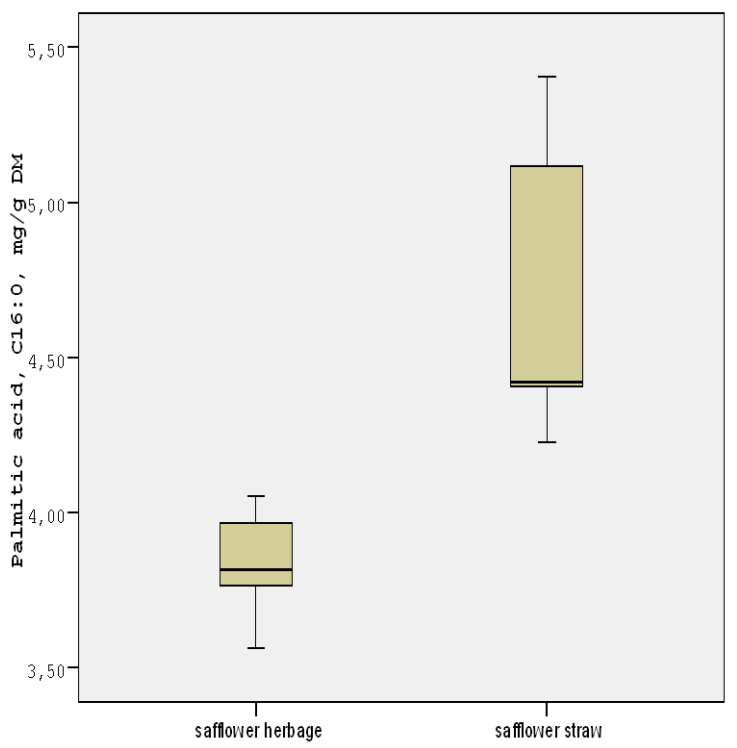

Figure 1. Palmitic acid (mg/g DM) content in safflower herbage and safflower straw

(Table 2).

The proportions of SFA, MCFA, VLCFA and w-3, and w- $3 / w-6$ ratio for fatty acids of safflower herbage were higher than those of safflower straw $(P<0.001)$. The compositions of UFA, MUFA, PUFA, w- $6, w-9$ and LCFA in total fatty acids of safflower straw were higher than those of safflower herbage $(P<0.001)$ (Table $3)$.

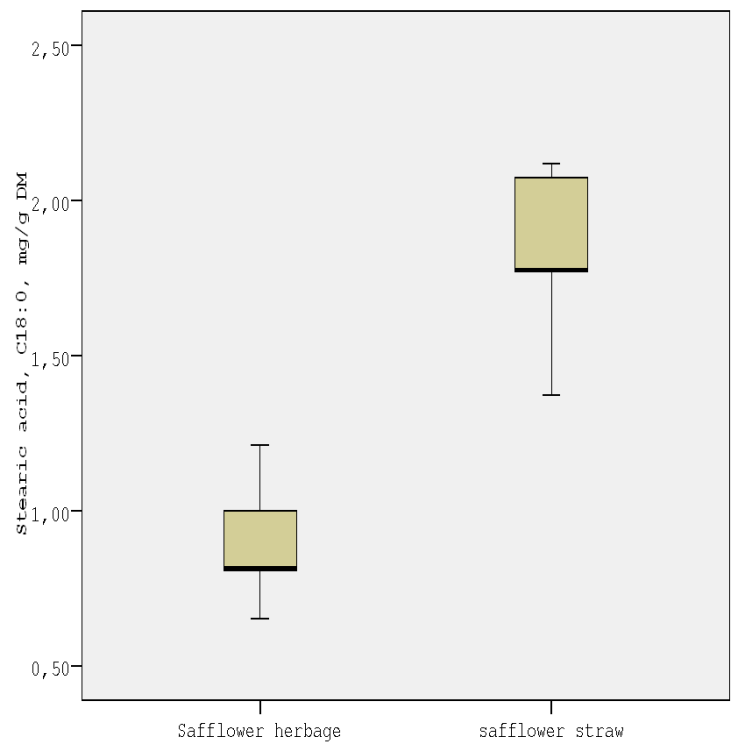

Figure 2. Stearic acid (mg/g DM) content in safflower herbage and safflower straw

Palmitic acid contents as $\mathrm{mg} / \mathrm{g}$ in DM of safflower herbage and safflower straw were 3.76 and 4.42 , respectively. Stearic acid contents of safflower herbage and safflower straw were 0.81 and $1.77 \mathrm{mg} / \mathrm{g}$ DM, respectively. Palmitic acid contents as $\mathrm{mg} / \mathrm{g}$ in DM of safflower herbage and safflower straw were 1.93 and 5.20 , respectively. Oleic acid contents in DM were $4.07 \mathrm{mg} / \mathrm{g}$ safflower herbage and $12.47 \mathrm{mg} /$ $\mathrm{g}$ safflower straw (Figures 1-4). 


\section{Discussion and Conclusion}

The concentration of average total fatty acid in differ-

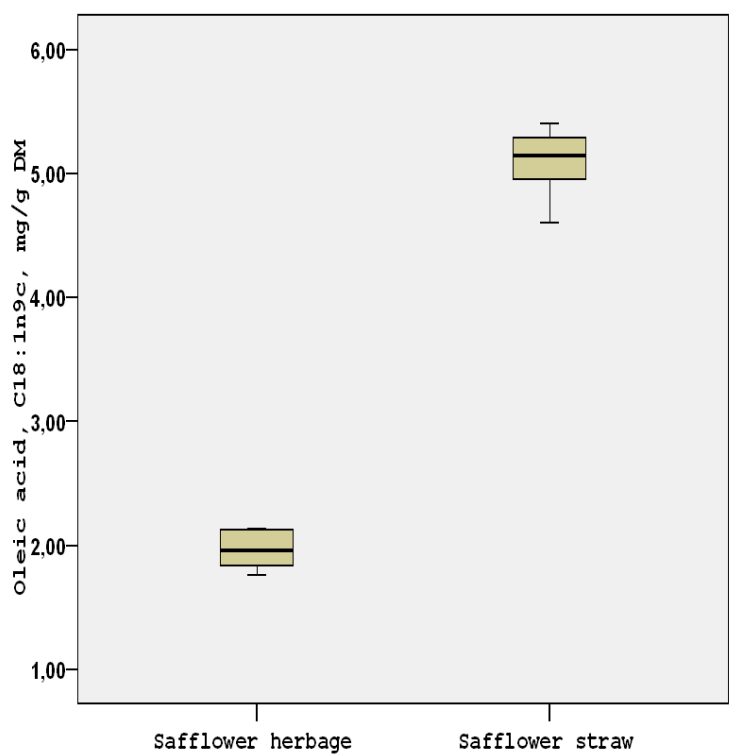

Figure 3. Oleic acid (mg/g DM) content in safflower herbage and safflower straw

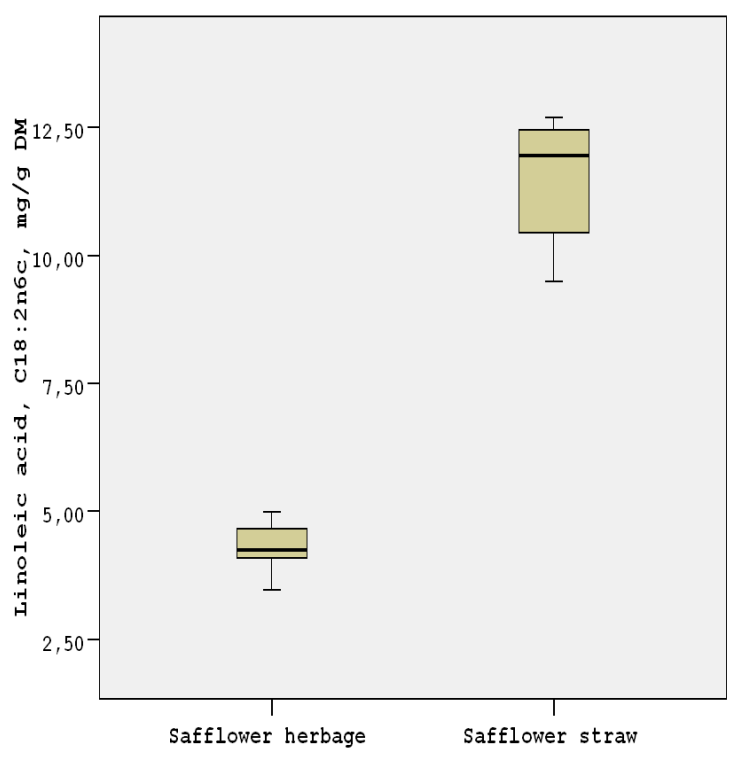

Figure 4. Linoleic acid (mg/g DM) content in safflower herbage and safflower straw

ent forages has been in the range of $2-5 \%$ in $D M$. Forages have often been the major and also the cheapest and safest source of FAs in ruminant diets. Forages are fibrous feedstuffs that should be present in their rations for healthy rumen physiology and ideal animal product quantity and quality in ruminant feeding (Kalac and Samkova, 2010). The nutrient contents of forages may differ depending on the species of plant (leguminous, cereals or other families), characteristics of the soil on which the plant grows, growth period of plant, feed technology applied to the plant (silage, drying, etc.) and storage time of forage/ fresh plant (Dewhurst et al., 2001; Mir et al., 2006; Dierking et al., 2010; Ersahince and Kara 2017; Kara et al., 2018). Especially unsaturated fatty acids are biohydrogenized by bacteria with biological activation in the rumen and their cis/trans configurations are changing. In addition to their biological functions in ruminant organism, these fatty acid metabolisms are the basis of the characteristic fatty acid profile in ruminant meat and milk acetic acid, which is the end product of fermentation, also has an important effect. In this respect, forages, which has both different fatty acids and high structural carbohydrate, also have an effect on animal health and functionality of animal products (Elgersma et al., 2006).

According to results of present study, individual fatty acid composition of safflower herbage and safflower straw, which consist of leaf, stem or bloom/flower, changed by the plant growing stage. The major fatty acids in safflower herbage were listed as follows: linoleic acid, palmitic acid, $\alpha$-linolenic acid, oleic acid and stearic acid, respectively. These fatty acids of safflower herbage were consisting of about $90 \%$ of total fatty acids. The major fatty acids in safflower straw were listed as follows: linoleic acid, oleic acid, palmitic acid and stearic acid, respectively. These fatty acids of safflower straw were consisting of about $93 \%$ of total fatty acids. The saturated fatty acid in highest concentration of safflower herbage (about $26 \%$ in total fatty acids) and safflower straw (about $17 \%$ in total fatty acids) in the present study was palmitic acid (C16:0). Researchers were determinate that C16:0 proportions in total fatty acids of common forages used in dairy cattle diet ranged from 15 to $30 \%$ for alfalfa (fresh, silage or hay), range from 16 to $20 \%$ perennial ryegrass, range from 14 to $20 \%$ for red clover (fresh, silage or hay), about $16 \%$ for white clover and about $16 \%$ for corn silage (Vanhatalo et al., 2007; Van Ranst et al., 2009; Dierking et al., 2010; Glasser et al., 2013). The stearic acid (C18:0) proportions of safflower forages in the current study ranged from 5.6 to 6.9. However, previous researchers demonstrated that C18:0 concentrations of legume forages and grasses used in dairy cattle ration were about 2-5\% in total fatty acids (Vanhatalo et al., 2007; Van Ranst et al., 2009; Dierking et al., 2010; Glasser et al., 2013). However, increasing the stearic acid level with growth of safflower in this study is compatible with the results of other reseachers for 
orchardgrass (Dactylis glomerata L.), perennial ryegrass (Lolium perennne L.) and tall fescue (Festuca arundinacea Schreb.) (Mir et al., 2006). The palmitic acid contents of safflower forages as $\mathrm{mg} / \mathrm{g}$ DM in present study were similar to results stated by Dierking et al. (2010) for tall fescue, tall fescue + alfalfa and tall fescue + red clover. The stearic acid contents of safflower forages as $\mathrm{mg} / \mathrm{g} \mathrm{DM}$ in the current study were similar to results of other forages (Dierking et al., 2010). In the present study, it has been observed that the proportions of palmitic acid and SFA in total fatty acids of safflower herbage, which was harvested at the beginning of flowering, decreased with plant growth. the palmitic acid amount in $\mathrm{mg} / \mathrm{g}$ DM of safflower herbage was lower than that of safflower straw. In addition, proportion of palmitic acid in total fatty acids of safflower herbage was lower than that of safflower straw. These interesting results can be related with increasing crude fat content (1.45 vs. $2.46 \%$ in DM) in straw making stage (or seed bulking stage) of safflower plant according to herbage, which harvested at early flowering stage.

The oleic acid (C18:1n9c), which was the highest MUFA in the present study, proportions in total fatty acids of safflower herbage and straw were about 13 and $20 \%$. The oleic acid and MUFA proportions in total fatty acid of safflower straw were higher than those of safflower herbage can be in relation with the lower part of flower and the upper part of flower in achene of safflower plant in seed bulking stage. In accordance with the results of the study, Mir et al. (2006) stated that oleic acid proportions in total fatty acids of orchard grass, perennial ryegrass and tall fescue increased with plant growing stage. The oleic acid contents as $\mathrm{mg} / \mathrm{g}$ DM of safflower forages in the present study were higher than the results specified by Khan et al. (2015) for some forages (Trifolium alexandrinum, Cichorium intybus, Medicago sativa and Avena sativa) at different stages.

The PUFA, MUFA, LCFA, w- 3 and w- 6 proportions in fatty acids of safflower straw were higher than those of safflower herbage may be related with the lower part of flower and the upper part of flower in achene of safflower plant in seed bulking stage. However, w3 and $\alpha$-linolenic acid (C18:3 n3) proportions in total fatty acids of safflower herbage were higher than those of safflower straw can be relation to the results of Mir et al. (2006), which designated C18:3 concentrations of some pasture plants decreased with plant maturating. Vanhatalo et al. (2007) and Boufaied et al. (2003) identified that C18:3 n3 and PUFA concentrations in green herbage harvested at early stage were higher than those of it harvested late. The concentrations of $>\mathrm{C} 22: 0$ fatty acids of safflower herbage were higher than those of safflower straw may be related with plant amount and phenological stage of plant. As the plant vegetation period progresses, the cell wall structural carbohydrate substances increase, and there is a decrease in the easily soluble carbohydrate, fat and protein levels in the endosperm (Kara et al., 2018). In the present study, it is seen that there is a significant change in the essential fatty acid components depending on the plant development period (safflower herbage and safflower straw). The differences in fatty acid profile of safflower forages according to the plant development period may be an important factor in plant type (Mir et al., 2006; Vanhatalo et al., 2007; Boufaied et al., 2003).

The high MUFA, w- 9 and LCFA concentrations in safflower herbage and straw in the present study indicate a rich forage in terms of MUFA (oleic acid) and $w-9$ fatty acids, which have a positive effect on fertility and embryo implantation in uterus of ruminant (Aardema et al., 2011). Aardema et al. (2011) investigated the effect of three fatty acids (saturated palmitic and stearic acid and unsaturated oleic acid) on lipid storage and development of oocytes in vitro and showed that palmitic and stearic acids had inhibitory effects on oocyte development, but oleic acid eliminated this adverse effect and showed positive effect. The low levels (mg/g DM) of palmitic and stearic acids in safflower herbage can reveal its advantage for dairy cattle fertility compared to safflower straw.

Although the crude protein and metabolic energy values of safflower straw were lower than those of safflower herbage, it has been reported that in vitro digestibility in beef cattle and horse diet of safflower straw was similar to those of safflower herbage by Cagri and Kara (2018). As a result of study, it is understood that the safflower herbage and safflower straw has a rich fatty acid content. The essential fatty acids, which have important biological activity, in the safflower straw, are high for unit dry matter consumed (as $\mathrm{mg} / \mathrm{g}$ in DM) shows the advantage of other straws. At the same time, the richness of safflower straw in terms of $w-9$ fatty acids (\% as in total fatty acids) indicates that it can be utilizable as forage for diet of infertility dairy cattle. In general, these forages stand out as rich alternative fibrous sources in $w-3$ and $w-6$ fatty acids.

\section{References}

Aardema $\mathrm{H}$, Vos PL, Lolicato $\mathrm{F}$, Roelen BAJ, Knijn $\mathrm{HM}$, Vaandrager AB, Helms JB, Gadella BM. Oleic acid prevents detrimental effects of saturated fatty acids on bovine oocyte developmental competence. Biol Reprod 2011: 85; 62-9.

Altin TB, Barak B, Altin BN. Change in precipitation and temperature amounts over three decades in central Anatolia, Turkey. Atmosph Clim Sci 2012; 2: $107-25$

Asgharzadeh F, Nasri MHF, Behdani MA. Effects of nitrogen and phosphorus fertilizers on nutritive value of safflower forage and silage. J Anim Poult 
Sci 2013; 3: 66-75

Baumler E, Cuniberti A, Nolascoa SM, Riccobene IC. Moisture dependent physical and compression properties of safflower seed. J Food Eng 2006; 72 : $134-40$

Boufaied H, Chouinard PY, Tremblay GF. Fatty acids in forages. I. Factors affecting concentrations. Can J Anim Sci 2003: 83; 501-11.

Cagri A, Kara K. The effect of safflower on the in vitro digestion parameters and methane production in horse and ruminant. Acta Vet Eurasia 2018; $44: 73$ -84 .

Dewhurst RJ, Scollan ND, Youell SJ. Influence of species, cutting date and cutting interval on the fatty acid composition of grasses. Grass Forage Sci 2001: 56; 68-74.

Dierking RM, Kallenbach RL, Roberts CA. Fatty acid profiles of orchardgrass, tall fescue, perennial ryegrass, and alfalfa. Crop Sci 2010: 50; 391-402.

Elgersma A, Dijkstra J, Tamminga S. Fresh Herbage for Dairy Cattle. the Netherlands: Springer 2006; pp: 175-94.

Ersahince AC, Kara K. Nutrient composition and in vitro digestion parameters of Jerusalem artichoke (Helianthus tuberosus L.) herbage at different maturity stages in horse and ruminant. J Anim Feed Sci 2017: 26; 213-25.

Gilbert J. International safflower productionan overview. 7th International Safflower Conference. November, 3rd-6th, 2008; Wagga Wagga, NSW- Australia.

Glasser F, Doreau M, Maxin G. Fat and fatty acid content and composition of forages: A metaanalysis. Anim Feed Sci Tech 2013; 185: 19-34.

Kalac P, Samkova E. The effects of feeding various forages on fatty acid composition of bovine milk fat: A review. Czech J Anim Sci 2010: 55; 521-37.

Kara K, Ozkaya S, Baytok E, Guclu BK,Aktug E, Erbas $\mathrm{S}$. Effect of phenological stage on nutrient composition, in vitro fermentation and gas production kinetics of Plantago lanceolata herbage. Vet Med (Czech) 2018; 63: 251-60.

Kara K. The investigation of milk urea nitrogen and milk fatty acids compositions in dairy cattle with subacute ruminal acidosis. Vet Med (Czech) 2020: $65 ; 1-8$.

Khan NA, Farooq MW, Ali M, Suleman M, Ahmad N, Sulaiman SM, Cone JW, Hendriks WH. Effect of species and harvest maturity on the fatty acids profile of tropical forages. J Anim Plant Sci 2015: 25(3); 739-46

Kramer JK, Feller V, Dugan ME, Sauer FD, Mossoba MM, Yurawecz MP. Evaluating acid and base catalysts in the methylation of milk and rumen fatty acids with special emphasis on conjugated dienes and total trans fatty acids. Lipids 1997; 32: 121928

Landau S, Friedman S, Brenner S, Bruckental I, GWeinberg Z, Ashbell G, Hen Y, Dvash L, Leshem $Y$. The value of safflower (Carthamus tinctorius) hay and silage grown under Mediterranean conditions as forage for dairy cattle. Livest Prod Sci 2004; 88: 263-71.

Landau S, Friedman S, Brenner S, Bruckental I, Weinberg ZG, Ashbell G, Hen Y, Dvash L, Leshem $Y$. Safflower (Carthamus tinctorius L.) as a novel pasture species for dairy sheep in the Mediterranean conditions of Sardinia and Israel. Small Rum Res 2005; 59: 239-49.

Mir PS, Bittman S, Hunt D Lipid content and fatty acid composition of grasses sampled on different dates through the early part of the growing season. Can J Anim Sci 2006: 86; 279-90.

Official Methods of Analysis (AOAC) Association of Official Analytical Chemists. 15th ed. Arlington, VA. 1995.

Turkey Statistical Institution (TUIK). Plant Production Statistics. Access address: http://www.tuik.gov.tr/ PreTablo.do?alt id=1001 Access date: 25.06.2020

Van Ranst G, Fievez V, Vandewalle M. Influence of herbage species, cultivar and cutting date on fatty acid composition of herbage and lipid metabolism during ensiling. Grass Forage Sci 2009; 64: 196 207.

Vanhatalo A, Kuoppala K, Toivonen V. Effects of forage species and stage of maturity on bovine milk fatty acid composition. Eur J Lipid Sci Tech 2007; 108: 856-67.

Wang J, Wu W, Wang X, Wang M, Wu F. An affective GC method for the determination of the fatty acid composition in silkworm pupae oil using a two -step methylation process. J Serb Chem Soc 2015: 80; 9-20. 
